\title{
Redescription of the type species of Diaphorocellus Simon, 1893 (Araneae, Palpimanidae, Chediminae)
}

\author{
Sergei L. Zonstein', Yuri M. Marusikik, 2,4, Mikhail M. Omelko ${ }^{5,6}$ \\ I Department of Zoology, Steinhardt Museum of Natural History, Tel-Aviv University, 69978 Tel-Aviv, Israel \\ 2 Institute for Biological Problems of the North RAS, Portovaya Str. 18, Magadan, Russia 3 Department of \\ Zoology \& Entomology, University of the Free State, Bloemfontein 9300, South Africa 4 Zoological Museum, \\ University of Turku, FI-20014 Turku, Finland 5 Far Eastern Federal University, Sukhanova, 8, Vladivostok \\ 690950, Russia 6 Gornotaezhnaya Station FEB RAS, Gornotaezhnoe Vil., Ussuriyski Dist., Primorski Krai \\ 692533, Russia
}

Corresponding author: Sergei L. Zonstein (znn@post.tau.ac.il)

Academic editor: Pavel Stoev | Received 23 July 2016 | Accepted 23 August 2016 | Published 31 August 2016

http://zoobank.org/7025D8FA-E4FA-4A7D-BAD7-73902C2CEA8D

Citation: Zonstein SL, Marusik YM, Omelko MM (2016) Redescription of the type species of Diaphorocellus Simon, 1893 (Araneae, Palpimanidae, Chediminae). African Invertebrates 57(2): 93-103. doi: 10.3897/AfrInvertebr.57.9988

\begin{abstract}
The type species of Diaphorocellus Simon, 1893, the South African D. biplagiatus Simon, 1893, is redescribed, and the male is described for the first time. The species is diagnosed and figured in detail, including the copulatory organs of both sexes, previously undescribed for any species of the genus. New distributional data of $D$. biplagiatus are provided.
\end{abstract}

\section{Keywords}

Taxonomy, Diaphorocellus biplagiatus, brush-footed spiders, endogyne, South Africa

\section{Introduction}

Diaphorocellus Simon, 1893 is a small genus of palpimanid spiders with four species distributed in the Afrotropical region (Platnick 2014, World Spider Catalog 2016). The genus has a complex and contradictory history. 
Simon (1893a,b) described the South African genus Diaphorocellus, and separately, D. biplagiatus Simon, 1893 (which was noted as the type species in the former study, but described only in the latter one) in two different publications. Both descriptions were based, as indicated by Simon (1893b: 315), on a single female. The genus was placed in Chedimae (=Chediminae Simon, 1893b). Soon after the description, Diaphorocellus was synonymised by Simon (1895) with Otiothops MacLeay, 1839, a genus currently known exclusively from the Neotropical region (cf. Platnick 2014). Later, Simon (1903) removed Diaphorocellus from synonymy with Otiothops and considered it a synonym of another Neotropical genus, Iheringia Keyserling, 1891. Platnick (1975) revalidated Diaphorocellus and "transferred" it to the Chediminae, although this genus has been already placed in the Chedimeae by Simon, since its description.

While resurrecting Diaphorocellus, Platnick (1975) did not mention any African species except the generotype. Meanwhile, two of them, D. helveolus (Simon, 1910) and D. rufus (Tullgren, 1910), were not previously considered in Diaphorocellus. Types of these species were not studied by Platnick, and new combinations were not suggested or indicated in his paper. In fact, both latter species were transferred to Diaphorocellus by Platnick (2000) without any formal indication of this transfer.

All genera in Chediminae were diagnosed by Simon (1893b) chiefly on the basis of eye sizes and interdistances. Besides eye pattern (large PMEs are subequal to AMEs and touch each other), D. biplagiatus differs from other genera and species of Palpimanidae by the presence of two light dorsal spots on the dark grey abdomen (Figs 1, 3-4). Since the description of the type species, only one species has been described in the genus, D. albooculatus Lawrence, 1927 from Namibia, based on three subadult males. This species has an abdominal pattern like that of $D$. biplagiatus.

Although Simon (1893a) stated that he described the female of D. biplagiatus, judging from the size $(4.5 \mathrm{~mm})$ the holotype should be a juvenile specimen. By contrast, syntypes of $D$. albooculatus are $8 \mathrm{~mm}$ and thought to be subadult males (as indicated by Lawrence 1927).

A male, recorded (but not described) by Lawrence (1936) as belonging to D. biplagiatus, was collected from Gemsbok Pan, North West Province, South Africa, near the Botswana border. This area is distant from the Cape (historically the area around Cape Town, modern Western Cape Province), but is very close to Kang, Botswana, the type locality of $D$. helveolus. Most likely, this male and also two females recorded by Lawrence (1936) for the neighbouring Tsortsoga Pan actually belong to the latter species.

It is notable that none of the species considered currently to be in the genus have illustrations of the endogyne or the male palp. Additionally, we were unable to find a detailed description of the very complex endogyne for any member of the subfamily. The existing more or less detailed figures given in Jézéquel (1964) lack any indication and description of the particular structures. Two papers by Platnick et al. (1999) and Piacentini et al. (2013) provide detail figures of the female copulatory organs with indication names of different strictures, but all illustrated species belong to different subfamily, Otiothopinae, and fine structures visible through dissecting microscope on high magnification like grape-shaped gland with cilia, fine threads, or pore fields are missing. 
To revise the genus, we studied numerous specimens from South Africa and adjacent states identified as $D$. biplagiatus. Although specimens from all over the country and adjacent Botswana have the same abdominal pattern and size, we recognised that specimens from the Western Cape clearly differ from specimens from Botswana and the eastern provinces of South Africa by the palp and the endogyne. We consider specimens from the Western Cape Province to be D. biplagiatus, and those from other areas to be D. helveolus.

\section{Material and methods}

Specimens from the following spider collections were studied:

MRAC Royal Museum for Central Africa, Tervuren, Belgium;

NCA National Collection of Arachnida, ARC-Plant Protection Research Institute, Pretoria, South Africa.

We examined over 40 specimens of $D$. biplagiatus and over a hundred specimens belonging to other species of Diaphorocellus. Although the number of specimens belonging to D. biplagiatus are high, they were collected in three localities only. In the "material examined" we list only selected samples containing males and females or samples from the exactly same locality collected in different dates.

Comparative material used in this study (selected samples):

Diaphorocellus sp. (nr. albooculatus): NAMIBIA: $10^{\Uparrow} 45 \mathrm{~km} \mathrm{~N}$ Okahandja, Prelude farm (32¹7'S, 19¹0'E), 16-25.x.1987, R. Jocqué (MRAC 168449).

Diaphorocellus helveolus: BOTSWANA: 10 , Okavango Delta, Pom Pom, 23.viii.2001, M. Dangerfield, pitfall traps, dry riparian (NCA 2001/417); 19 same, near Shakawe (18²1'S, 2150'E), 29.xi.2006, C. Haddad (NCA 2007/978).

Diaphorocellus rufus: TANZANIA: $1{ }^{\Uparrow} 1$ 우 Mkomazi Game Reserve, 27.xi.1994, A. Russell-Smith (MRAC 215487).

Photographs were taken using a Zeiss Discovery V20 stereomicroscope with a Canon PowerShot G9 camera and an Olympus SZX16 stereomicroscope with an Olympus E-520 camera and prepared using CombineZP software. Scanning electron micrographs were made using the SEM JEOL JSM-5200 scanning microscope at the Zoological Museum, University of Turku, Finland. Illustrations of scuta and endogynes were made after maceration in a $20 \%$ potassium hydroxide aqueous solution and exposure for a few minutes in an alcohol/water solution of Chlorazol Black. Endogynes were photographed on slides either with an Olympus SZX16 or an Olympus BH-2. Small pieces of cotton were used to fix the copulatory organs in the correct position. Measurements were made to an accuracy of $0.01 \mathrm{~mm}$. Lengths of leg and palp segments were measured on the dorsal side, from the midpoint of the anterior margin to the midpoint of the posterior margin. All measurements are given in millimetres. 
The following abbreviations are used:

$\begin{array}{ll}\text { ALE } & \text { anterior lateral eyes } \\ \text { AME } & \text { anterior median eyes } \\ \text { Ce } & \text { base of cymbium encircling bulb } \\ \text { Cg } & \text { cilia of grape-shaped gland } \\ \text { CL } & \text { carapace length } \\ \text { Cs } & \text { strong cymbial setae } \\ \text { CW } & \text { carapace width } \\ \text { Da } & \text { dark area in basal part of receptacle } \\ \text { Em } & \text { "embolus" } \\ \text { Ft } & \text { fine threads } \\ \text { Gg } & \text { grape-shaped gland } \\ \text { Ls } & \text { lateral sclerite } \\ \text { Mo } & \text { membranous outgrowth } \\ \text { Ms } & \text { median sclerite } \\ \text { PLE } & \text { posterior lateral eyes } \\ \text { PME } & \text { posterior median eyes } \\ \text { Re } & \text { receptacle } \\ \text { Rs } & \text { membranous sac-shaped part of receptacle } \\ \text { So } & \text { sclerotized outgrowth } \\ \text { Sb } & \text { complex sclerotised base of receptacle } \\ \text { TL } & \text { total length of body in dorsal view }\end{array}$

\section{Taxonomy}

\section{Genus Diaphorocellus Simon, 1893}

Diaphorocellus: Simon 1893: 314; Platnick 1975: 5.

Type species. Diaphorocellus biplagiatus Simon, 1893, by monotypy.

Notes. Since its description, the genus has always been considered a member of the Old World subfamily Chediminae Simon, 1893. Diaphorocellus can be easily recognised by the large PME that are very close or even touching each other (as in Fig. 8). Only Otiothops MacLeay, 1839, a representative of the New World subfamily Otiothopinae Platnick, 1975, has similarly shaped and arranged PMEs (Grismado and Ramírez 2002: fig. 2; Buckup and Ott 2004: fig. 1; Grismado 2008: fig. 1). However, Diaphorocellus differs from this genus by the presence of the accessory structures on the male palp accompanying the embolus (Figs 11-19) that are characteristic of the Chediminae but absent in the Otiothopinae (see Platnick 1975; Platnick et al. 1999). The genus includes four poorly known species recorded from Botswana, Namibia, South 
Africa and Tanzania (Platnick 2014; World Spider Catalog 2016). None of these species have been reconsidered since their original descriptions and no illustrations of the endogyne or the male palp have been provided until now.

\section{Diaphorocellus biplagiatus Simon, 1893}

Figs 1-26

Diaphorocellus biplagiatus Simon 1893a: 405, fig. 366; 1893b: 314 ()); Platnick 1975: 5. Iheringia biplagiata: Simon 1910: 180; Lawrence 1936: 149 (ठُ; only record; questionable).

Diagnosis. The species can be distinguished from $D$. albooculatus by eye arrangement: in D. biplagiatus, the distance between the AMEs is two times less than their diameter, whereas in $D$. albooculatus, the distance is subequal; the shape of the ventral scuta of the males also differs (cf. Fig. 7 and Lawrence 1936: fig. 54). D. helveolus can be distinguished from $D$. biplagiatus by the abdomen lacking long whitish hairs (vs. an abdomen covered with long whitish hairs in the latter). Diaphorocellus biplagiatus can be distinguished from $D$. rufus by the abdominal colouration (bicolorous in the former species vs. uniformly dark in the latter), as well as by the shape of the ventral scuta in females (cf. Fig. 2 and Tullgren 1910: fig. 29).

Redescription. Male (NCA 2008/4672).

Habitus: as in Figs 1, 4, 7. Measurements: TL 4.90, CL 1.84, CW 1.25. Colour in alcohol: carapace and chelicerae dark carmine-red; palps and legs I intense reddishorange; legs II-IV light yellowish-orange; sternum, labium and maxillae intense red; abdomen dorsally brown with two large longitudinal median bright yellowish spots (one in anterior half of abdomen and another at the abdominal tip above the spinnerets), divided by a wide transverse brown bridge, ventrally uniformly light yellow. Carapace: with coarse granulations (Fig. 5). Eye measurements: AME 0.12, ALE 0.08, PLE 0.07, PME 0.14, AME-AME 0.06, AME-ALE 0.06, AME-PME 0.11, ALEPLE 0.04, PLE-PME 0.12, PME-PME <0.01 (touching each other). Palp: as shown in Figs 11-19. Trochanter long, longer than patella. Femur subequal in length to tibia+cymbium, 3 times longer than wide; patella globular. Tibia strongly swollen, wider than long, 1.7 times wider than femur, with large cavity enclosing cymbium. Retrolateral basal part of cymbium with set of 9 very long (as long as cymbium) and strong setae $(C s)$, setae curled in terminal part. Base of cymbium envelops (encircles) entire bulb $(C e)$. Tegulum globular, approximately $1 / 2$ of cymbium length and subequal to width of patella; spermophor absent; top of tegulum with membranous circular cavity containing 3 outgrowths: 1) long, heavily sclerotised, deeply bifurcated in terminal part with 3 sharply pointed tips $(S o), 2)$ long, membranous (almost invisible under light microscope) lamella with barbed tip $(M o)$, 3) gutter-like in terminal part, weakly sclerotised "embolus" $(E m)$. Embolus without distinct opening, which is most likely hidden in the basal part. 


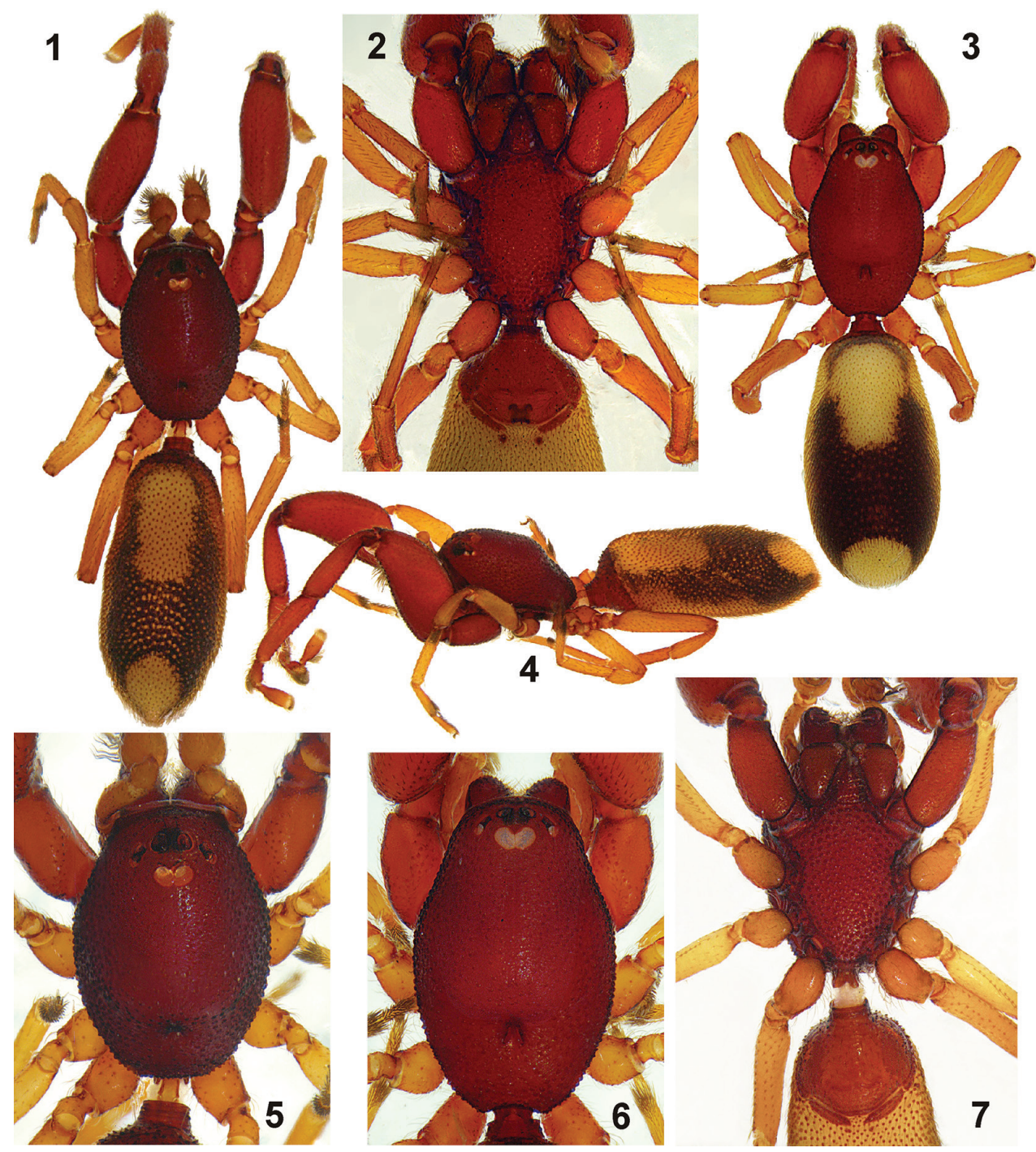

Figures I-7. Habitus of Diaphorocellus biplagiatus male (I, 4-5, 7) and female (2-3, 6). I, 3 entire body, dorsal 2, 7 prosoma and anterior part of abdomen, ventral 5-6 prosoma, dorsal.

Leg measurements: male NCA 2008/4672 (female NCA 2008/2607 in parentheses):

\begin{tabular}{l|c|c|c|c|c|c}
\hline & Femur & Patella & Tibia & Metatarsus & Tarsus & Total \\
\hline Palp & $0.50(0.69)$ & $0.14(0.18)$ & $0.27(0.41)$ & - & $0.29(0.42)$ & $1.20(1.57)$ \\
\hline I & $1.49(1.52)$ & $1.07(1.28)$ & $0.99(1.13)$ & $0.37(0.44)$ & $0.51(0.51)$ & $4.43(4.88)$ \\
\hline II & $1.03(1.20)$ & $0.61(0.74)$ & $0.76(0.85)$ & $0.53(0.71)$ & $0.42(0.45)$ & $3.35(3.95)$ \\
\hline III & $0.86(0.97)$ & $0.49(0.70)$ & $0.60(0.74)$ & $0.56(0.79)$ & $0.43(0.46)$ & $2.94(3.66)$ \\
\hline IV & $1.35(1.34)$ & $0.77(0.85)$ & $1.03(1.26)$ & $0.91(1.13)$ & $0.54(0.57)$ & $4.60(5.15)$ \\
\hline
\end{tabular}



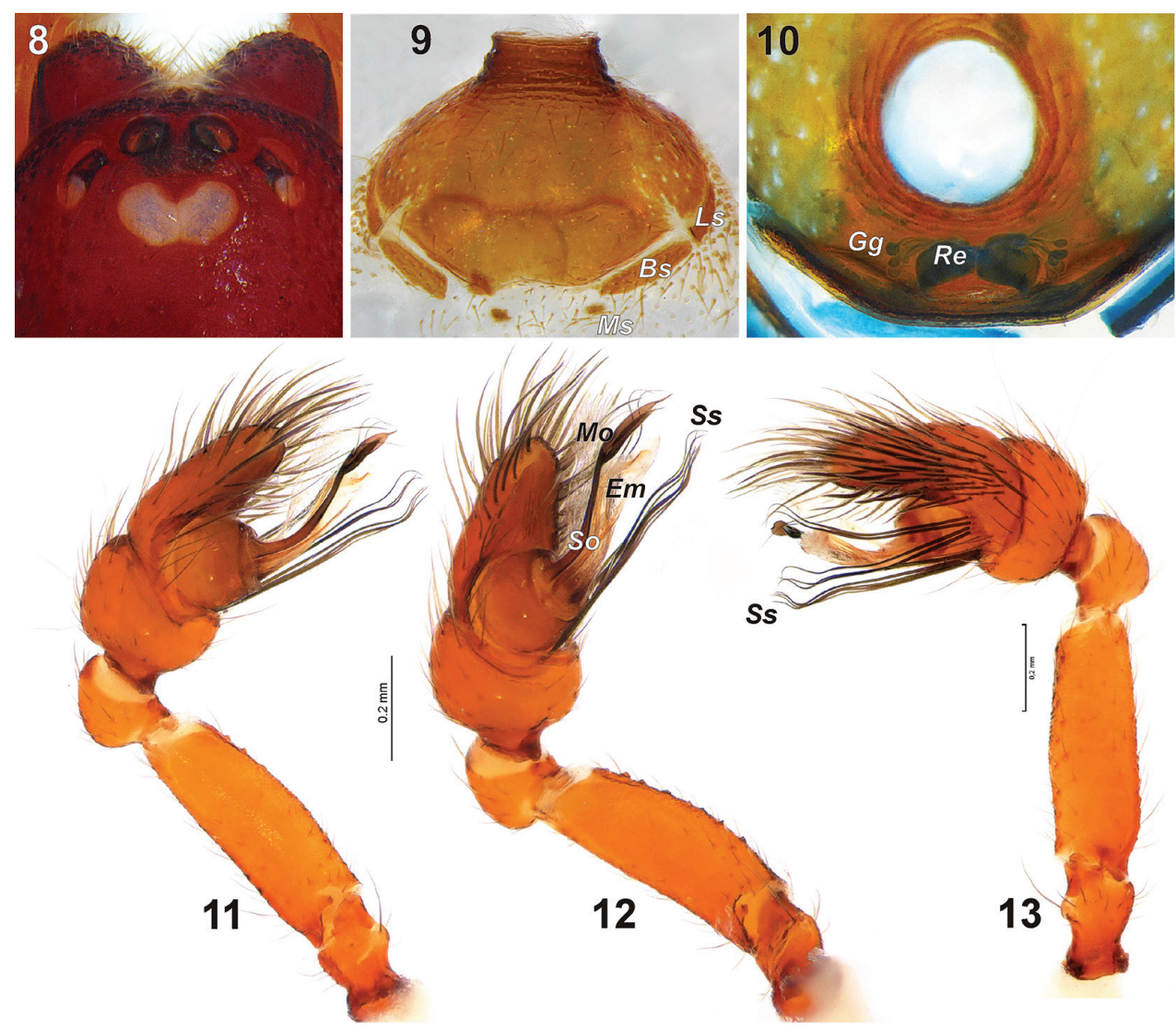

Figures 8-13. Diaphorocellus biplagiatus. 8 eye pattern in female, dorsal 9 epigastric scutum, female, ventral $\mathbf{1 0}$ epigastric scutum after maceration, caudal view I I-I $\mathbf{3}$ male palp, prolateral, ventro-prolateral and retrolateral. Abbreviations: Bs sclerite opposite to book lungs; $C s$ strong cymbial setae; Em "embolus"; $G g$ grape-shaped gland; $L s$ lateral sclerite; $M o$ membranous outgrowth; $M s$ median sclerite; $R e$ receptacle; So sclerotised outgrowth.

Female (NCA 2008/2607).

Habitus: as in Figs 2, 3. Measurements: TL 5.47, CL 2.83, CW 1.48. Colour in alcohol: as in male, but leg I coloured similarly to legs II-IV (but not darker, contrary to that of male). Carapace: longer, with less coarse granulations than in male (Fig. 6). Eye measurements: AME 0.13, ALE 0.09, PLE 0.08, PME 0.18, AME-AME 0.06, AME-ALE 0.06, AME-PME 0.11, ALE-PLE 0.03, PLE-PME 0.11, PME-PME $<0.01$ (touching each other - Fig. 8). Leg measurements: as shown above in parentheses. Genital area and receptacles: as in Figs 20-26. Genital plate accompanied by 3 pairs of sclerites lying on postgastral (posterior from epigastric furrow): two small dot-like median sclerites $(M s)$ and 2 pairs of longitudinal sclerites, one pair stretched along book-lung spiracle $(B s)$, and another pair on lateral sides of endogyne $(L s)$. Endogyne formed by pair of receptacles. Receptacle $(R e)$ consists of complex sclerotised base $(S b)$ 

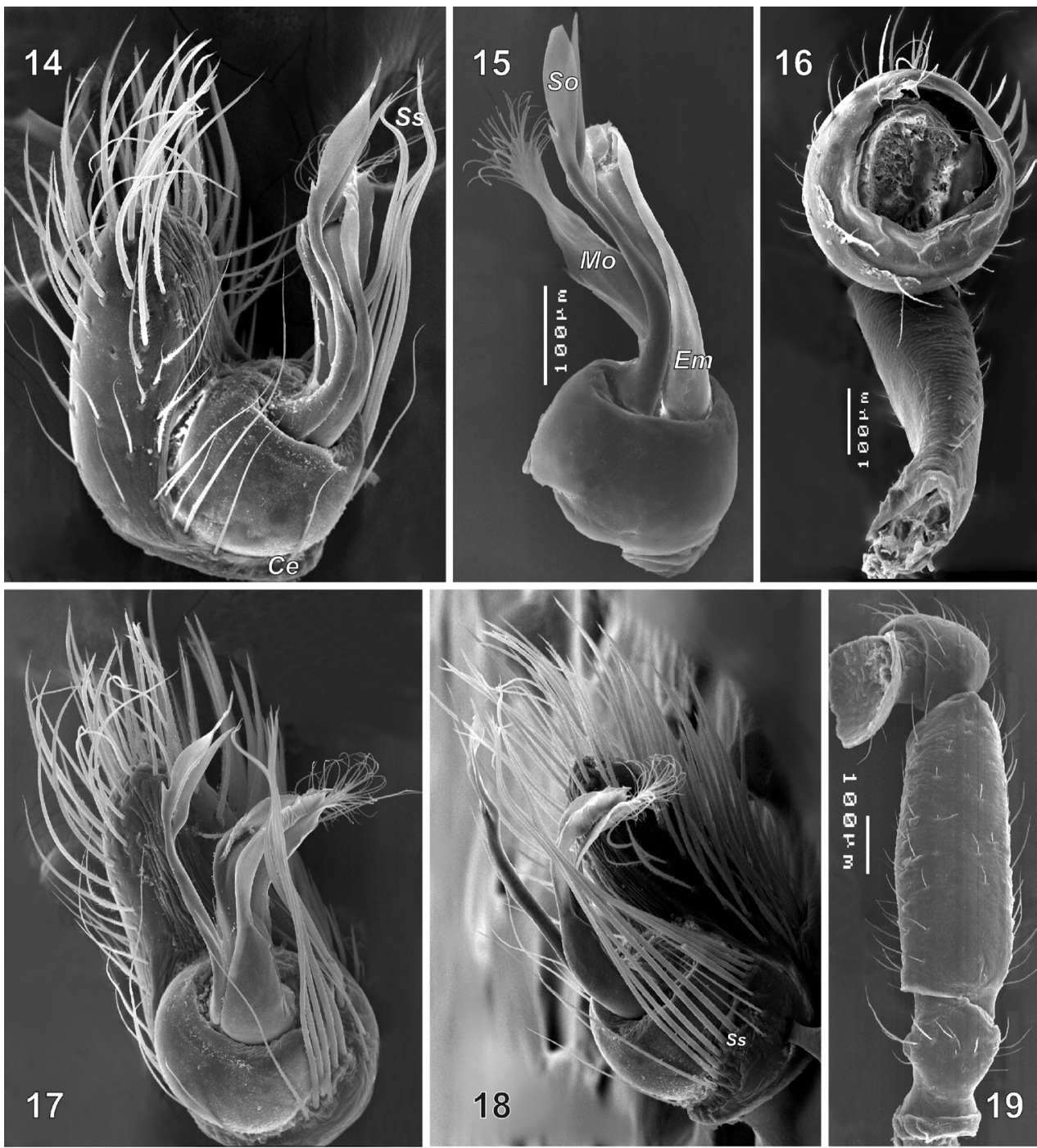

Figures 14-19. Details of male palp of Diaphorocellus biplagiatus. 14, 17-18 cymbium and bulb, prolateral, ventro-prolateral (from above) and retrolateral $\mathbf{I} \mathbf{5}$ bulb, prolateral $\mathbf{I} \mathbf{6}$ femur and tibia, ventral 19 trochanter, femur and patella, retrolateral. Abbreviations: $C e$ base of cymbium encircling bulb; $C s$ strong cymbial setae; Em "embolus"; Mo membranous outgrowth; So sclerotised outgrowth.

and large, transparent, membranous sac $(R s)$. Base of receptacle accompanied with approximately 10 grape-shaped glands $(G g)$ attached to receptacles by long thread-like stems and brushes of fine threads $(F t)$. Base of receptacle subconical, anterior part of receptacle with dark area $(D a)$ composed of numerous pores. Base of receptacle and grape-shaped gland covered with small thread-like cilia. Cilia $(C g)$ on glands shorter and originating from pore-like base. 

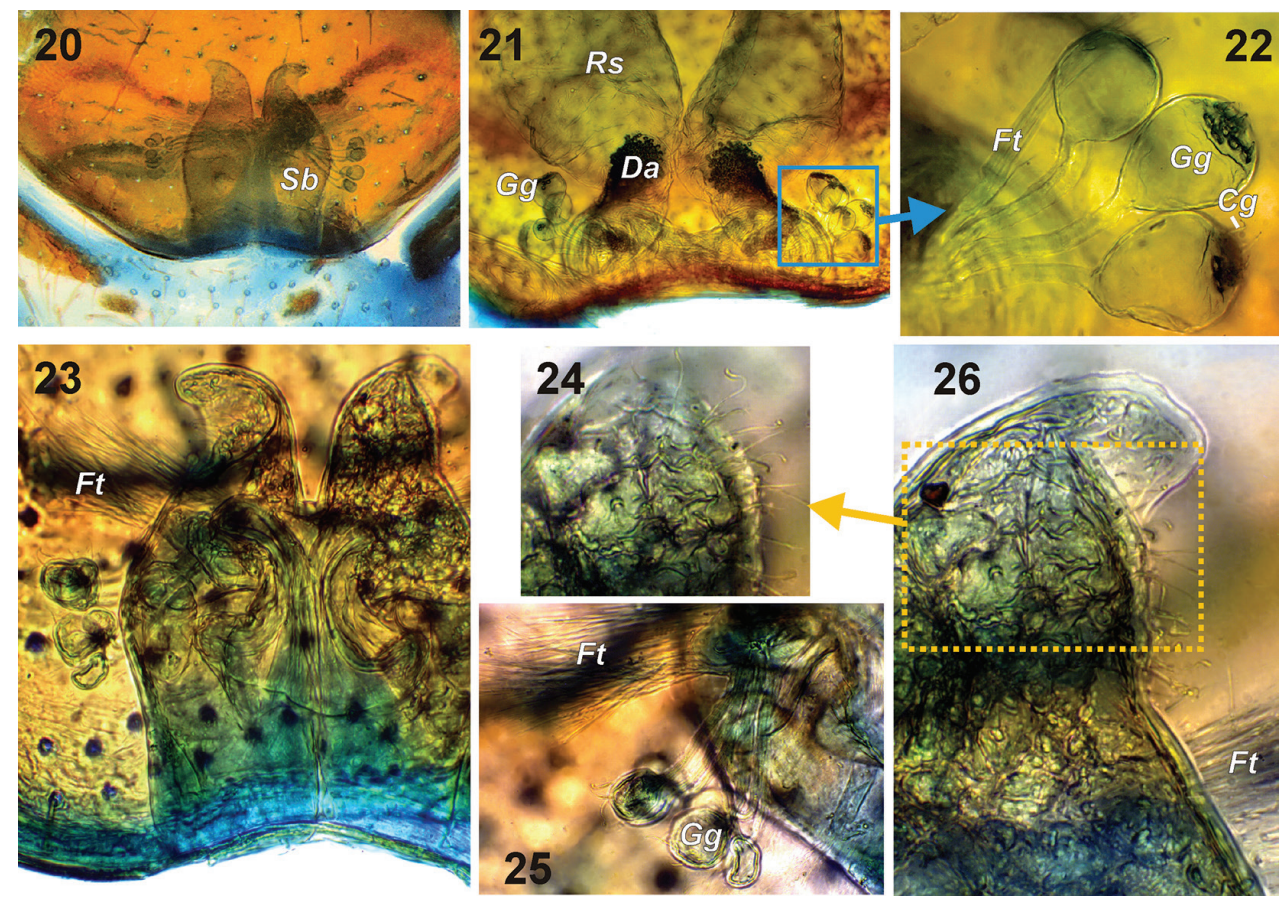

Figures 20-26. Details of endogyne of Diaphorocellus biplagiatus. 20 dorsal $\mathbf{2 I}$ basal part, caudal-dorsal $\mathbf{2 2}$ grape-shaped glands $\mathbf{2 3}$ base of receptacles, dorsal $\mathbf{2 4}$ tip of base showing cilia $\mathbf{2 5}$ lateral part of receptacle base showing grape-shaped glands and fine threads $\mathbf{2 6}$ terminal part of receptacle base $\mathbf{2} \mathbf{1 - 2 6}$ made by transmitting microscope. Abbreviations: $C g$ cilia of $G g$; Da dark area of $S b$; Ft fine threads; $G g$ grapeshaped gland; $R s$ membranous sac like part of $R e ; S b$ complex sclerotised base of $R e$.

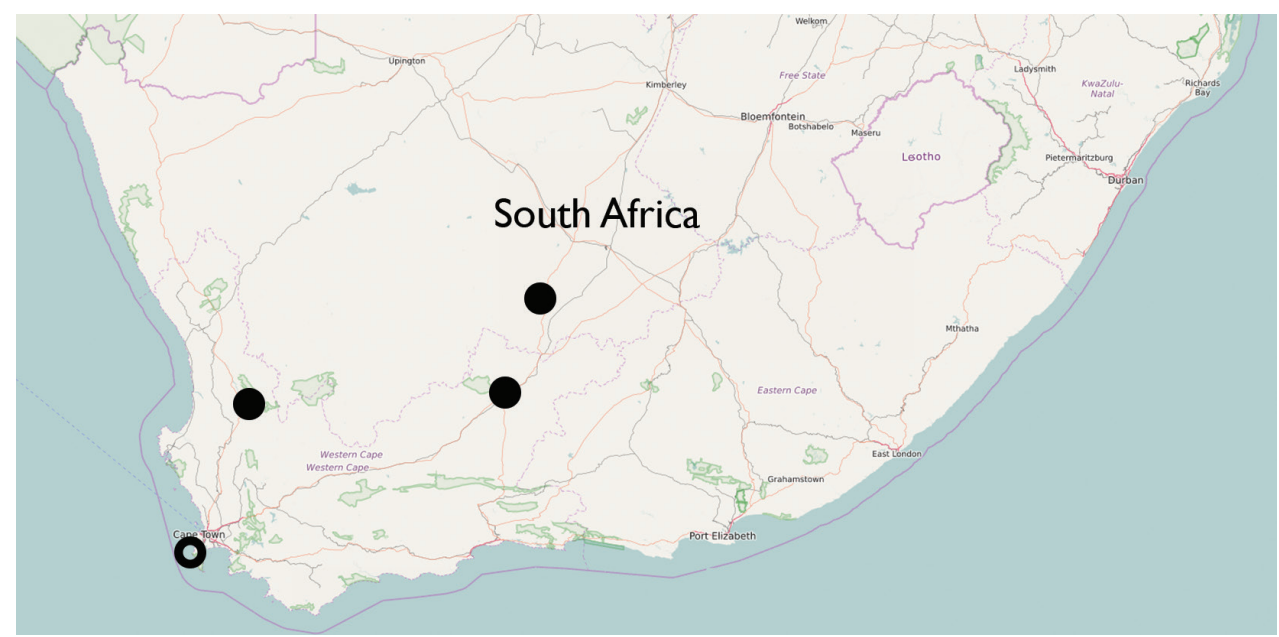

Figure 27. Distribution of Diaphorocellus biplagiatus. The type locality (open circle) and new records listed in the text (solid circles). 
Holotype. + (probably immature) - SOUTH AFRICA: Western Cape: "Caput Bonæ-Spei" (Cape of Good Hope), with no other data provided. MNHN; borrowed to date by another museum, thus not examined.

Material examined (selected samples). SOUTH AFRICA: Western Cape: $1 \delta^{\lambda}$ Beaufort-West, Farm Katdoornkuil (32.7093 ${ }^{\circ}$ S, 22.7538 ${ }^{\circ}$ E), 3-6.xii.2007, D.H. Jacobs, pitfall traps, Karoo bush (NCA 2008/4672); 1 q same, Farm Kantkraal $\left(32.7605^{\circ}\right.$ S,

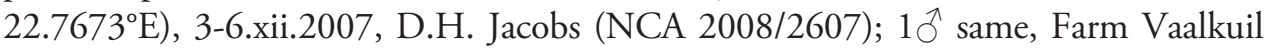
(32.8139 $\left.\mathrm{S}, 22.7818^{\circ} \mathrm{E}\right), 3-6 . x i i .2007$, D.H. Jacobs (NCA 2008/2673); $1 \mathrm{O}^{\lambda}$ same, Farm Bokvlei (32.4331 $\left.{ }^{\circ} \mathrm{S}, 23.3535^{\circ} \mathrm{E}\right), 11-14 . x i i .2007$, D.H. Jacobs (NCA 2008/4676); $1 \mathrm{O}^{\lambda}$ 1 ㅇ same, Farm Eerste Water $\left(32.6887^{\circ} \mathrm{S}, 22.9610^{\circ} \mathrm{E}\right)$, 6-9.xii.2007, D.H. Jacobs (NCA 2008/4675); $10^{\lambda}$ Cederberg Wilderness Area, Wupperthal (32 $\left.16.757^{\prime} \mathrm{S}, 19^{\circ} 13.200^{\prime} \mathrm{E}\right)$, 515 m, 6.x.2009, S. Kritszinger-Klopper (NCA 2011/2739); 19 same, Sneeukop, (3221.141'S, $\left.19^{\circ} 10.073^{\prime} \mathrm{E}\right), 1680$ m, 1-31x.2004, E. Nortje, S. Kritszinger-Klopper (NCA 2011/1129); $1 \delta^{\lambda}$ Cederberg, Sederhoutkloof (32 $\left.{ }^{\circ} 17^{\prime} \mathrm{S}, 19^{\circ} 10^{\prime} \mathrm{E}\right), 1100-1200 \mathrm{~m}$,

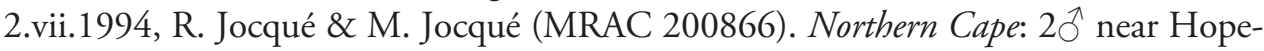
town, Suffolk Farm $\left(29^{\circ} 35.691^{\prime} S, 24^{\circ} 15.505^{\prime} E\right), 20 . i .2008$, R. Lyle, R. Fourie, D. du Plessis, J. Adendorff, K. Lyle, karooveld (NCA 2009/4162).

Distribution. South Africa (Western and Northern Cape) (Fig. 27).

Natural history. Most specimens were collected in karoo bush with pitfall traps.

\section{Acknowledgements}

We thank Ansie Dippenaar-Schoeman and Petro Marais (NCA) and Rudy Jocqué (MRAC) for loaning us the material used for this study. English of the earlier draft was edited by Sarah Crews (Oakland, California, USA). We also are grateful to reviewers for their comments that greatly improved the manuscript. This study was partially supported by the Ministry of Absorption, Israel. This work was also supported in part by the Far Eastern Federal University (Vladivostok) and by grant of President of the Russian Federation (MK-6046.2016.4).

\section{References}

Buckup EH, Ott R (2004) Espécies novas de Otiothops e Fernandezina do norte do Brasil (Araneae, Palpimanidae). Iheringia, Série Zoologia 94: 23-24.

Grismado CJ (2008) Descripción de una nueva especie de Otiothops Mac Leay (Arachnida, Araneae, Palpimanidae) de Misiones, Argentina. Natura Neotropicalis 37: 39-42.

Grismado CJ, Ramírez MJ (2002) Descripción de una nueva especie de Otiothops MacLeay de la Argentina, y notas sobre el género (Araneae, Palpimanidae, Otiothopinae). Revista del Museo Argentino de Ciencias Naturales, Nueva Serie 4: 99-103.

Jézéquel J-F (1964) Araignées de la savane de Singrobo (Côte d'Ivoire). II. Palpimanidae et Zodariidae. Bulletin du Muséum National d'Histoire Naturelle de Paris 36: 326-338. 
Lawrence RF (1927) Contributions to a knowledge of the fauna of South-West Africa V. Arachnida. Annals of the South African Museum 25(1): 1-75.

Lawrence RF (1936) Scientific results of the Vernay-Lang Kalahari Expedition, March to September 1930. Spiders (Ctenizidae excepted). Annals of the Transvaal Museum 17: $145-158$.

Piacentini LN, Ávila Calero SL, Pérez ME, Grismado CJ (2013) The first palpimanid spiders from Bolivia: two new species of the genus Otiothops MacLeay, and the female of Fernandezina pulchra Birabén (Araneae: Palpimanidae: Otiothopinae). Zootaxa 3619: 491-500. doi: 10.11646/zootaxa.3619.4.6

Platnick NI (1975) A revision of the palpimanid spiders of the new subfamily Otiothopinae (Araneae, Palpimanidae). American Museum Novitates 2562: 1-32.

Platnick NI (2000) The world spider catalog, version 1.0. American Museum of Natural History. http://research.amnh.org/iz/spiders/catalog [accessed on 20.viii.2016]

Platnick NI (2014) The world spider catalog, version 15.0. American Museum of Natural History. http://research.amnh.org/iz/spiders/catalog [accessed on 20.08.2016]

Platnick NI, Grismado CJ, Ramírez MJ (1999) On the genera of the spider subfamily Otiothopinae (Araneae, Palpimanidae). American Museum Novitates 3257: 1-25.

Simon E (1893a) Histoire naturelle des araignées. Paris 1: 257-488.

Simon E (1893b) Études arachnologiques. 25e Mémoire. XL. Descriptions d'espèces et de genres nouveaux de l'ordre des Araneae. Annales de la Société Entomologique de France 62: 299-330.

Simon E (1895) Arachnides recueillis à la Terre-de-feu par M. Carlos Backhausen. Anales del Museo Nacional de Historia Natural de Buenos Aires 4: 167-172.

Simon E (1910) Arachnoidea. Araneae (II). In: Schultze L (Ed.) Zoologische und anthropologische Ergebnisse einer Forschungsreise im Westlichen und zentralen Südafrika. Denkschriften der Medizinisch-Naturwissenschaftlichen Gesellschaft zu Jena 16: 175-218.

Tullgren A (1910) Araneae. In: Sjöstedt Y (Ed.) Wissenschaftliche Ergebnisse der Schwedischen Zoologischen Expedition nach dem Kilimandjaro, dem Meru und dem Umbegenden Massaisteppen Deutsch-Ostafrikas 1905-1906 unter Leitung von Prof. Dr Yngve Sjöstedt. Stockholm 20(6): 85-172.

World Spider Catalog (2016) World Spider Catalog. Natural History Museum Bern, version 17.5. http://wsc.nmbe.ch [accessed on 20.viii.2016] 